\title{
DOUTRINA
}

\section{OBSERVAÇÕES SOBRE AGÊNCIAS REGULADORAS DE SERVIÇO PÚBLICO}

\author{
ANTÔNio Carlos Cintra do AMARAL
}

No l Congresso Brasileiro de Direito Público, realizado em São Paulo em abril de 2000, e no Il Seminário Internacional Sobre Agências Reguladoras, realizado em Brasília em setembro de 2001, tive oportunidade de proferir palestras sobre agências reguladoras de serviço público. A primeira dessas palestras foi incluída em meu livro "Comentando as Licitações Públicas" (Rio de Janeiro, Editora Temas \& Idéias, 2002). Ambas foram divulgadas neste site (www.celc.com.br), a primeira em 15.11.2000 e a segunda em 15/10/2001.

No momento atual, muito se tem discutido sobre o assunto. Por isso, volto a ele nesta página, com brevíssimas observações formuladas esquematicamente a seguir.

1. Costuma-se falar, genericamente, em "agências reguladoras", sem se fazer uma distinção essencial à adequada compreensão do assunto. Não se percebe que não há um, mas três tipos de agências reguladoras" no Direito brasileiro. Vejamos.

2. O Poder Público tem a atribuição constitucional de regular a atividade econômica, devendo para isso exercer as funções de fiscalização, incentivo e planejamento, este, determinante para o setor público e indicativo para o setor privado (art. 174 da Constituição). Exemplos de agências que exercem esse papel regulador são a ANVS (vigilância sanitária) e a ANS (saúde suplementar).

3. A Constituição atribui especificamente à União o monopólio das atividades econômicas referentes a petróleo, gás natural e outros hidrocarbonetos fluidos. A Agência Nacional de Petróleo (ANP) tem por função regular essas atividades quando contratadas com empresas estatais ou privadas (art. 177 e $\S \S 1^{\circ}$ e $2^{\circ}$ ).

4. O terceiro tipo de "agência reguladora" decorre da competência constitucional do Poder Público para prestar serviço público, direta ou indiretamente, neste caso mediante concessão ou permissão (art. 175). Para regular a prestação de serviços 
públicos por concessionárias ou permissionárias, foram criadas, na esfera federal. a ANATEL (telecomunicações), a ANEEL (energia elétrica), a ANTT (transportes terrestres) e a ANTAQ (transportes aquaviários). As agências reguladoras de serviço público, diferentemente das dos outros dois tipos, regula o exercício, por empresa privada, de atividade (serviço público) atribuída pela Constituição ao Poder Público, que - frise-se - continua com a titularidade do serviço concedido ou permitido.

5. Feita esta distinção - que, repito, é essencial à adequada compreensão do assunto - , passarei a tratar especificamente das "agências reguladoras de serviço puiblico".

6. A função atribuída pelo Direito brasileiro a essas agências é una função técnica. A formulação da política geral para o setor regulado (telecomunicações, energia elétrica, transportes, fornecimento de gás canalizado, fornecimento de água e esgotamento sanitário) deve ser efetuada por leis e regulamentos. Cabe à agência celebrar os contratos de concessão e regular e fiscalizar seu cumprimento, tudo na conformidade das leis e regulamentos em vigor. A Constituição não autoriza a delegação da função legislativa a essas entidades. O fato de a Constituição prever a criação de um órgão regulador dos serviços de telecomunicações (art. 2I, XI) não autoriza, como alguns pretendem, a delegação à ANATEL do poder de legislar a respeito. Quanto às demais agências reguladoras de serviço público, sua criação sequer está prevista no texto constitucional.

7. As agências reguladoras são entidades integrantes do Poder Executivo. Como tais, os atos praticados por seus dirigentes, ao contrário do que muitas vezes se tem sustentado, estão submetidos ao controle dos tribunais de Contas, bem como aos demais controles a que estão sujeitos os atos administrativos em geral, especialmente o controle jurisdicional.

8. As agências reguladoras deveriam exercer o importante papel de defensoras do usuário de serviço público. Não o estão fazendo, ou pelo menos não o estão fazendo adequadamente, deixando um vazio que tem sido preenchido pelo PROCON.

9. Em parte, isso se deve ao fato de que elas ainda não estão devidamente estruturadas. Sua criação, organização e estruturação deu-se a reboque das privatizações dos serviços públicos, quando devia ter sido condição necessária al essias privatizações, como acentuei na palestra proferida no I Congresso Brasileiro de Direito Público, acima referida.

10. Em parte. porém, isso se deve a que o Congresso Nacional não aprovou até agora a Lei de Defesa de Usuário de Serviços Públicos, o que, de acordo com o art. 27 da Emenda Constitucional $n^{\circ} 19 / 98$, deveria ter feito até outubro de 1998. Por força da inércia do Legislativo, tem sido aplicado à defesa dos usuários de serviço público o Código de Defesa do Consumidor, que pode ser muito bom, mas é inadequado para regular a relação de serviço público. juridicamente diversa da relação de consumo. Na relação de serviço público (de direito público), o poder concedente mantém a titularidade do serviço, transferindo seu exercício à concessionária privada. Continua ele com a responsabilidade pela sua prestação "adcquada", ou seja, é solidariamente responsável pelo cumprimento das obrigaçōes assumidas pela concessionária perante os usuários. Na relação do consumo, o Poder Público regula a relação (de direito privado) existente entre fornecedor e consumidor, 
com vista a proteger aquele considerado hipossuficiente, não tendo nenhuma responsabilidade pelo cumprimento das obrigações do fornecedor perante o consumidor (sobre essa distinção, ver o texto correspondente à palestra no Il Seminário Internacional sobre Agências Reguladoras, acima mencionada).

11. Finalmente: as agências reguladoras de serviço público têm um importante papel a desempenhar e para isso precisam contar com acentuado grau de autonomia. Em nenhuma hipótese, porém, é aceitável a tese de que elas devam equiparar-se ou sobrepor-se aos poderes constituídos. Isso seria incompatível com o Estado de direito. Nesse sentido, parece-me que muitas das normas legais disciplinadoras da atuação dessas agências estão em flagrante conflito com a ordem constitucional. 


\section{Teoria e Prática do Direito Marítimo}

Carla Adriana Comitre Gibertoni

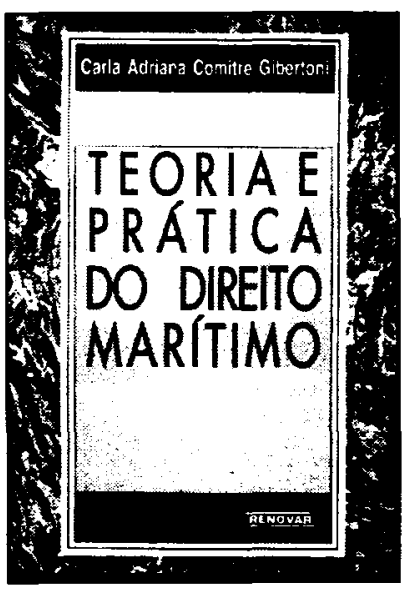

Nesta obra a autora apresenta informaçōes atualizadas $\mathrm{e}$ indispensáveis sobre o assunto no âmbito nacional, tais como: a prática da navegação, o Tribunal Marítimo e suas decisōes, os Acidentes e Fatos da Navegação, o Seguro Marítimo, o Transporte Marítimo e a responsabilidade civil e a Lei de modernização dos portos, que tanto interfere nas atividades portuárias.

Ref. 0183

Form. 14x21

Brochura

1998

508 págs.

\section{Tratado de Direito Comparado Introdução ao Direito Comparado \\ Leontin-Jean Constantinesco}

Com este trabalho, o autor procura justamente individualizar os critérios através dos quais inserir essa imagem fragmentária do Direito numa visāo unitária que tente compreender o Direito na atual situação espaço-temporal. Não é mais possível continuar confundindo legislação alienígena com Direito Comparado.

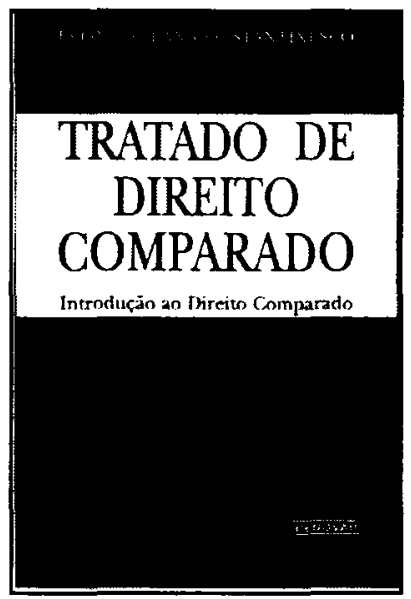

Ref. 0182

Brochura

404 págs.

Form. $14 \times 21$ 1998 